\title{
VAI, MALANDRA. O DESPERTAR ONTOLÓGICO DO PLANETA FOME ${ }^{1}$
}

\author{
Armando de Melo Lisboa ${ }^{2}$ \\ Universidade Federal de Santa Catarina
}

(Elza Soares, em 1953 no programa de calouros de Ary

Barroso, diante de uma plateia que, impressionada com sua esquálida e desarranjada figura, a recebeu com risos e vaias. Após este diálogo pode cantar, e então Ary e a plateia, deslumbrados, a ovacionaram de pé).

\section{Resumo}

Empreendimentos populares de todos os tipos são legião e com tal amplitude que perfazem uma progressiva ruptura com a subalternização da maioria do povo brasileiro, levando a uma inserção criativa na vida global à revelia de projetos cupulistas de "nação" conduzidos por pseudos demiurgos salvadores.

Palavras-chave: Ontologia política. Desenvolvimento territorial. Economia popular. Segunda descolonização. Negócios inclusivos.

\section{"VAI, MALANDRA". GO, CHEEKY GIRL. THE PLANET HUNGER ONTOLOGICAL AWAKENING.}

\begin{abstract}
A multitude of popular entrepreneurs is embodying a growing disruption of the subordinate condition in which the majority of the Brazilian people is living, leading to their creative inclusion in the global ways of life in clear defiance of the elitist projects of "nation" conducted by pseudo saviors and demiurges.
\end{abstract}

Keywords: Political ontology. Territorial development. Popular economy. Second decolonisation. Inclusive business.

\section{INOVAÇÕES LIBERTÁRIAS DOS CONDENADOS DA TERRA}

“As periferias são laboratórios de mundos e a riqueza do Brasil. Não mais os pobres assujeitados e excluídos de certo imaginário e discurso, mas uma ciberperiferia, a riqueza da pobreza (disputada pela Nike, pela

Globo, pelo Estado) que transforma as favelas, quilombos urbanos conectados, em laboratórios de produção subjetiva. A carne negra das favelas, os corpos potentes e desejantes, a cooperação sem mando, inventando espaços e tempos outros (na rua, nos bailes, lanhouses e lajes), estão sujeitos a todos os tipos de apropriação. É que as favelas e periferias são o maior capital nas bolsas de valores simbólicas do país, pois converteram as forças hostis máximas (pobreza, violência, Estado de exceção) em processo de criação e invenção cultural"

(Bentes, 2014).

\footnotetext{
${ }^{1}$ Este texto retoma a reflexão sobre um projeto "Brasil-Nação" e já exposta em http://www.ihu.unisinos.br/78noticias/567524-os-novos-demiurgos-da-nacao.

${ }^{2}$ Professor no Depto. de Economia e Relações Internacionais da UFSC.
} 
Uma irrupção extraordinária de riqueza proveniente da diversidade brasileira emerge incontidamente quando se desfazem as castradoras amarras seculares que mantém o império do planeta fome nas terras tupiniquins. Nossas periferias surpreendentemente transcendem o eterno abandono do Estado e o genocida massacre diário e constante dos corpos morenos e negros perpetrado por sua força policial. Nelas "uma pobreza potente, inventa mundos, modas, gírias, linguagem, inventa a sua própria vida" (Bentes, 2017).

1) Em 1993 Zica Assis e Leila Velez abriam um salão de beleza num fundo de quintal da periferia do Rio de Janeiro voltado aos cabelos crespos e público afro. Desabrochada na rede "Instituto Beleza Natural"3, inauguraram em 2017 uma filial com 600 metros quadrados em Nova York, a qual se soma as 45 unidades de negócio em operação e que mobilizam uma fábrica própria ("Cor Brasil Cosméticos") e uma equipe de 3 mil colaboradoras para atender mensalmente em seus salões mais de 130 mil clientes.

Tendo por lemas "Beleza Natural: uma fábrica de autoestima"; "Bonito é ser você"; "Solte seus cachos" e "Bonito é saber transformar beleza em atitude", Zica Assis já figura entre as dez mulheres de negócios mais poderosas do Brasil, segundo a revista "Forbes", enquanto Leila Velez foi escolhida em 2014 pelo Fórum Econômico de Davos como uma das jovens líderes (menos de 40 anos) mais influentes no mundo.

Assim como a Beleza Natural, existem inúmeros outros empreendimentos bem sucedidos que brotam nas periferias urbanas brasileira. Vale também salientar alguns cases que visam promover e potencializar as mesmas:

"Favela Holding"4: rede de empresas criada por Celso Athayde (RJ, 1963) com a missão de oportunizar negócios para as favelas e seus moradores, especialmente junto a empreendedores comunitários, esforço que levou a fundação da "Liga dos Empreendedores Comunitários (LEC)".

"Agência Solano Trindade": busca fortalecer a economia de cultura criativa, incentivando a produção e difusão de ações culturais populares de forma a alcançarem viabilidade econômica. Para tal, entre outras iniciativas, mantém o Banco Comunitário União Sampaio, onde se emite uma moeda alternativa, \$ampaio. Atuando na região do Campo Limpo, Capão Redondo e adjacências, periferia da cidade de São Paulo, esta espécie de

\footnotetext{
${ }^{3}$ http://www.belezanatural.com.br/. Heloiza (Zica) Assis, nascida no Rio de Janeiro em 1961, foi babá aos nove anos, depois empregada doméstica e faxineira. A também carioca Leila (1974), era ex-atendente do McDonald's, sendo promovida à gerente quando tinha 16 anos.

${ }^{4}$ https://www.fholding.com.br/o-grupo.php. Para fomentar a economia comunitária nas favelas, Athayde, afrodescendente, ex-morador de rua e ex-coordenador da CUFA, Central Única das Favelas (https://www.cufa.org.br/sobre.php), vem estabelecendo diversas parcerias com empresários e lideranças, entre os quais o rapper MV Bill.
} 
coworking da periferia surgiu em 2012 por iniciativa de Thiago Vinicius (São Paulo, 1989), um dos fundadores do Banco Comunitário, para impulsionar empreendimentos nascidos naquelas comunidades. Ele defende que "a periferia não precisa de assistencialismo. Precisa crescer sem depender de ninguém"5.

2) Iniciativas populares em saúde perfazem uma cativante ebulição que expressa a sociobiodiversidade brasileira, ou seja, o conhecimento tradicional passado de geração em geração da nossa inestimável e inigualável biodiversidade, a maior do planeta. Mesmo sendo difícil destacar algo em particular, pois são milhares os casos bem sucedidos, seguem alguns exemplos:

As "Farmácias Vivas", surgidas a partir da experiência do prof. Francisco José de Abreu Matos (CE, 1924-2008) ${ }^{6}$, disseminaram por todo país hortos fitoterápicos, geralmente associados a hospitais. Recolhendo o conhecimento popular em ervas e plantas medicinais, este programa se exponencializa ao se enlaçar com as Pastorais da Saúde por todos os rincões do Brasil, inspirando a criação, da "Política Nacional de Plantas Medicinais e Fitoterápicos", adotada pelo SUS (Sistema Único de Saúde).

Uma iniciativa das Pastorais da Saúde e da Criança merece realce: a "Farinha Multimistura", indicada algumas vezes ao Nobel da Paz, através de Zilda Arns (SC, 19342010), por reduzir substancialmente a desnutrição e a mortalidade infantil brasileira. Criada por Clara Brandão ${ }^{7}$, a Multimistura difundiu-se em todos os estados brasileiros e em mais 15 países da América Latina, África e Ásia.

5 Solano Trindade foi um dos criadores da "poesia negra" no Brasil. Mais informações em: https://agenciasolanotrindade.wordpress.com/quem-somos/

${ }^{6}$ Abreu Matos é farmacêutico-químico diplomado em 1945 pela Faculdade de Farmácia do Ceará, um dos embriões da futura Universidade Federal do Ceará (UFC), universidade que ajudará a criar.

“A partir de inúmeras expedições percorrendo o interior do Ceará e do Nordeste do Brasil, sempre na companhia do prof. Afrânio Fernandes, botânico, coletando espécies vegetais e informações da sabedoria popular/tradicional sobre suas aplicações na saúde, o professor Matos se dedicou a interpretar e transformar em conhecimento cientifico o conhecimento empírico que absorvia. O projeto Farmácias Vivas foi criado como forma de devolver a ciência das plantas medicinais para a comunidade, levando-lhe o ensinamento do seu uso correto.

Nesse intenso trabalho de pesquisa etnobotânica, etnofarmacológica, taxonômica, bibliográfica e experimental (ensaios químicos e toxicológicos), foi selecionada mais de uma centena de espécies vegetais medicinais tendo como critérios imprescindíveis o reconhecimento de seu potencial de eficácia terapêutica e segurança de uso, as quais passaram a integrar o elenco do projeto Farmácias Vivas" (SANTOS; FONSECA: 2012).

${ }^{7}$ Filha de imigrantes japoneses, Clara Takaki Brandão (SP, 1944) formou-se em medicina em 1969 pela USP, com especialização em pediatria e, posteriormente, como nutróloga. No âmbito de um programa de orientação alimentar, desenvolveu a Multimistura a partir de 1975 quando de sua vivência na Amazônia. Em 1983, a Sociedade Brasileira de Pediatria concedeu à Dra. Clara o prêmio Álvaro Bahia de melhor trabalho contra a mortalidade infantil pelo uso da Multimistura (in: http://multimistura.org.br/biografia.htm). Registre-se que a Multimistura é objeto de uma forte controvérsia com entidades profissionais da área da nutrição. 
Também na linha dos fitoterápicos sobressai a "Farmacopéia do Cerrado" de pesquisa de centenas de raizeiros e raizeiras que formaram a "Articulação Pacari”, uma rede de grupos comunitários que praticam a medicina tradicional no Cerrado, surgida em 1999.

Progressivamente se impõe o movimento pela humanização do parto, despontado a partir dos anos 1970 (quando, não por acaso, ecoava a crítica de Ivan Illich ao excesso de medicalização da saúde) com o Prof. José Galba Araújo (CE, 1917-1985)9 ${ }^{9}$, o qual apoiava as práticas tradicionais de parteiras e índios, e vem a desembocar na "Rede pela Humanização do Parto e do Nascimento (Rehuna)", fundada em 1993. Num país que detém até o presente o triste recorde de cesarianas, a luta pelo parto natural tem ainda imensa relevância e promete, infelizmente, uma longa duração.

Ainda no Ceará, e daqui irradiado para o mundo, surge o movimento da "Terapia Comunitária", cujo pioneiro é Adalberto Barreto ${ }^{10}$. Iniciada numa favela em Fortaleza em 1987, hoje estende-se pelo Brasil, através das redes Associação Brasileira de Terapia Comunitária Integrativa (ABRATECOM) ${ }^{11}$ e Movimento Saúde Mental Comunitária $(\mathrm{MSMC})^{12}$, e pela América Latina, África e Europa, como a Association Europeenne de Therapie Communautaire Integrative ${ }^{13}$.

Por ser de domínio público, este conjunto de práticas e conhecimentos é vivenciado cotidianamente de forma generalizada, beneficiando multidões. Dentre as políticas nacionais moldadas por estas experiências também se evidencia o relevante e consolidado "Programa de Agentes Comunitários de Saúde (PACS)", no âmbito do Ministério da Saúde. Mas, existem inúmeras instituições voltadas para um público de baixa renda que aplicam esta visão global e holística em saúde de forma intensiva e profissionalizada, atendendo com sucesso casos agudos e já desenganados, como o "Instituto Ecumênico Popular L'amigo (IEP)""

3) Também na periferia de Fortaleza (CE), no bairro Palmeira, nasceu o "Banco Palmas", talvez o mais expressivo fenômeno da vertente popular da economia solidária brasileira. No âmbito da luta pela melhoria do que era então uma das mais carentes áreas da capital cearense, surge a Associação de Moradores do Conjunto Palmeira (ASMOCONP). Esta,

\footnotetext{
${ }^{8} \mathrm{http}: / /$ www.pacari.org.br/farmacopeia-popular-do-cerrado/livro-farmacopeia-popular-do-cerrado/

${ }^{9}$ Médico obstetra e professor da UFC, Galba de Araújo foi diretor da Maternidade Escola Assis Chateaubriand da Universidade Federal do Ceará de 1964 a 1985. Desde 1999 o Ministério da Saúde outorga o "Prêmio Galba de Araújo" para condecorar profissionais e instituições dedicadas a humanização da atenção à mulher, ao recémnascido e que estimulam o parto natural e o aleitamento materno.

${ }^{10}$ Premiado internacionalmente, Barreto é professor no curso de Medicina da UFC, possuindo doutorados em psiquiatria e antropologia na França, além de graduação em Filosofia e Teologia em Roma em 1976.

${ }^{11} \mathrm{http} / / / \mathrm{www}$. abratecom.org.br/QuemSomos/Abratecom/

${ }^{12}$ http://www.msmcbj.org.br/

${ }^{13}$ https://www.aetci-a4v.eu/

${ }^{14}$ http://ieplamigo.com.br/
} 
sob a liderança de Joaquim Melo (CE, 1962), diante da carência de recursos financeiros, criou em 1998 o Banco Palmas, adotando de imediato algumas práticas financeiras para o desenvolvimento local, tais como um cartão de crédito próprio, o PalmaCard, e a emissão de sua própria moeda, o Palmares. Deste embrião amadureceu a "Rede Brasileira de Bancos Comunitários", hoje formada por 103 bancos comunitários ${ }^{15}$.

4) Os bem sucedidos empreendimentos camponeses de base familiar e agroecológicos também são legião. Na contramão da "modernização dolorosa" (Graziano da Silva) que aprofundou a concentração fundiária, o êxodo rural, a exclusão social e o uso de venenos, e convergindo com dinâmicas globais de recampesinação, eles são frutos da ampla luta e mobilização em prol da agricultura sustentável e familiar, impactando amplamente a sociedade brasileira, a qual cada vez mais opta e consome os produtos orgânicos. Entre eles sobressai-se a “Associação dos Agricultores Ecológicos das Encostas da Serra Geral (Agreco)" "16, fundada em 1996 e hoje gerando um faturamento equivalente a metade do orçamento do seu município de origem, Santa Rosa de Lima (SC), tornando-se a principal referência do mesmo. Vem desenvolvendo agroindústrias rurais de pequeno porte e o premiado programa de agroturismo "Acolhida na Colônia", o qual ganhou vida própria e mantém-se como um dos principais parceiros da Agreco $^{17}$.

Da mesma região da Agreco, mas atuante em toda a Região Sul, advém a "Rede Ecovida de Agroecologia" ${ }^{18}$, erguida em 1998 para aglutinar dezenas organizações e

\footnotetext{
15 http://www.institutobancopalmas.org/. O Banco Palmas gestou dentro do bairro uma rede de empresas e Inúmeros projetos socioeconômicos, tais como: PalmaTur (promoção do turismo no Conjunto Palmeira); Palma Fashion (confecções e calçados); Palma Limpe (materiais de limpeza; Loja Solidária e Feira (para comercializar os produtos fabricados no bairro); PalmaNatus (sabonetes e fitoterápicos); Bairro Escola de Trabalho (capacitação profissional); Incubadora Feminina; Companhia Bate Palmas (empreendimento de educação, arte e cultura, com ênfase na música); Curso de Consultores Comunitários; Academia de Moda Periferia; PalmaTech (escola para capacitação e gestão de empresas); Escola Popular Cooperativa Palmas (pré-vestibular); Comício Inverso (evento na praça pública no período eleitoral onde a população do bairro sobe no palanque para relatar seus problemas e apontar soluções, e os candidatos a prefeito e vereadores escutam sentados).

${ }^{16} \mathrm{http} / / / \mathrm{www} \cdot$ agreco.com.br/

${ }^{17}$ www.acolhida.com.br. Outras organizações parceiras da Agreco e surgidas a partir da mesma são: CEFAE Centro de Formação em Agroecologia Jean Yves Griot (www.cfaeagroecologia.com); DoDesign-s (www.dodesign-s.com.br) - escritório especializado em design para negócios orgânicos, comércio justo, alimentos gourmet e projetos ligados à sociobiodiversidade. Também já premiado nacional e internacionalmente; Boa Vista SS Ltda - empresa voltada para a geração de projetos inovadores e sustentáveis social, ambiental e economicamente; AMESG - Associação de Meliponicutores das Encostas da Serra Geral de Santa Catarina entidade criada para promover as abelhas nativas (sem ferrão) e difundir a produção e uso do mel de melíponas; Editora O Ronco do Bugio - instituição criada para apoiar o jornal comunitário CANAL SRL, produzido, em boa medida, por jovens agricutores(as) das comunidades rurais. Também estimulou a implantação da filial brasileira da Ecocert (http://brazil.ecocert.com/), certificadora de origem francesa responsável pela inspeção da produção orgânica dos produtos da Agreco.

${ }^{18}$ http://ecovida.org.br/. Além da presença em mais de uma centena de feiras e lojas, a Rede Ecovida possui box para a venda atacadista de produtos orgânicos na Ceasa/SC, otimizando a comercialização e os ganhos de escala da agricultura familiar.
} 
movimentos sociais e centenas de cooperativas e grupos de agricultores que constroem uma alternativa ao modelo de agricultura dominante no país. Ela criou o "Sistema Participativo de Garantia”, uma forma de certificação coletiva que responsabiliza os produtores e que configura uma tecnologia social que reduziu imensamente os custos de auditoria e certificação de orgânico, hoje disseminada mundialmente.

Este revigoramento do "campesinato" também está presente na Região Sisaleira, em pleno coração da Bahia e do Cerrado brasileiro, onde cresceu a cooperativa "APAEB Associação de Pequenos Agricultores do Estado de Bahia", fundada em 1980 para produzir e comercializar tapetes e carpetes de sisal de forma a desenvolver sustentavelmente sua região. $\mathrm{Na}$ transformação do sisal, produzido por cerca de 1.200 agricultores, a APAEB emprega mais de 900 pessoas no município de Valente ${ }^{19}$.

5) As vozes dos povos indígenas ecoam cada vez mais alto, e não apenas na luta pelos seus direitos e afirmação das suas culturas, mas também através da qualidade com que estão a gerar renda, riqueza e conhecimento. Com diversos pontos comerciais de venda (como nas lojas da Tok\&Stok e Pão de Açúcar), o belíssimo artesanato do povo Baniwa (Alto Rio Negro/AM) é ofertado em todo Brasil e até no exterior. Este caso bem sucedido de Comércio Justo é fruto do cuidadoso projeto "Arte Baniwa"20, gestado na parceria deste povo com o ISA - Instituto Socioambiental. Na região de São Gabriel da Cachoeira, conhecida como "Cabeça do Cachorro" (pelo seu formato no mapa do Brasil), maior e mais relevante território indígena brasileiro, os 23 povos indígenas lá presentes se organizaram desde 1987 em torno da FOIRN - Federação das Organizações Indígenas do Rio Negro. ${ }^{21}$

Brilha também o projeto "Vídeo nas aldeias" ${ }^{22}$, premiado nacional e internacionalmente. Surgido em 1986 com o trabalho de Vincent Carelli (França, 1953) no "Centro de Trabalho Indigenista", este projeto utiliza dos recursos audiovisuais para fortalecer a cultura e identidade dos povos nativos. Ailton Krenak (MG, 1953), cofundador da União das Nações Indígenas (1980) e uma das principais presenças indígenas nas discussões da Assembleia Constituinte, idealizou uma amostra de filmes indígenas, a "Aldeia SP", que em 2016, em sua segunda edição, se denominou "Bienal de Cinema Indígena", apresentando 57 filmes recentemente produzidos por eles, com uma forte amostra de produção feminina.

\footnotetext{
${ }^{19}$ http://www.apaeb.com.br/empresa.html. A APAEB vem investindo em projetos socioeducativos e econômicos, tais como: produção queijo e iogurte com leite de cabra; apicultura; Escola Familiar Agrícola; Rádio da Cidadania; Reflorestamento; Centro de Informática; Clube Social; TV Valente.

${ }^{20} \mathrm{http}: / /$ www.artebaniwa.org.br/

${ }^{21} \mathrm{http} / / / \mathrm{www}$.foirn.org.br/

${ }^{22}$ http://www.videonasaldeias.org.br/2009/index.php
} 
6) Dentro do vigoroso ramo da arquitetura e construção brasileiras, registro apenas a premiação há pouco obtida por um edifício erguido com base nas tecnologias indígenas, logrando o prêmio BREEAM Awards 2018 como melhor edifício sustentável das Américas ${ }^{23}$ face seu conforto térmico, utilização máxima da iluminação natural e da água de chuva. Tratase do "Centro Sebrae de Sustentabilidade (CSS)", em Cuiabá (MT), projetado pelo arquiteto José Portocarrero. Destaco da notícia:

\begin{abstract}
As casas indígenas resistem muito mais, não são derrubadas pelo tempo, porque são construções aerodinâmicas e reduzem em $30 \%$ a força do vento. $\mathrm{O}$ ar passa ali como respiração", afirma Portocarrero, que já visitou 28 aldeias indígenas em suas pesquisas. "Não foi um índio ou um arquiteto, mas gerações de indígenas que desenvolveram essas tecnologias, desde o desenho até os materiais de construção de uma estrutura espacial.
\end{abstract}

7) No meio do oceano de práticas educativas inclusivas, a rede de cursos pré-vestibular popular desponta como uma das mais relevantes. Superando a exclusividade dos caros cursinhos, ela oferece para um público de baixa renda cursos de baixo custo ou gratuitos, contribuindo decisivamente para romper as barreiras que excluíam o pobre e o negro da escola pública e assim reduzir a abissal desigualdade educacional, especialmente no acesso à universidade pública. Tal esforço perfaz uma verdadeira revolução silenciosa.

Entre os anos 1970 e 1980 surgem as primeiras e isoladas experiências de cursinhos populares, mas na década de 90 elas se alastram com vigor, fazendo-se presentes em todos os rincões deste país. Não há um levantamento recente, mas dados de 2001 dão conta da existência de 800 núcleos em todo país (ZAGO, 2008: 151). Na Baixada Fluminense, por exemplo, um dos pioneiros é o cursinho "Educafro" (1992) $)^{24}$, organização fundada e dirigida por frei David dos Santos (MG, 1952) e mantida pelo Serviço Franciscano de Solidariedade. Na Baixada também aflorou o "Movimento de Cursos Pré-Vestibulares para Negros e Carentes (PVNC)"25, rede com diversos núcleos de ensino.

Também buscando reverter o quase nulo acesso dos indígenas à universidade, um espaço tradicionalmente ligados as elites e praticamente anti-indígena, destacam-se a partir dos anos 2000 tanto o esforço dos cursos formação de professores indígenas ${ }^{26}$, quanto a via das

23 http://www.caubr.gov.br/arquiteto-do-brasil-vence-premio-de-melhor-edificio-sustentavel-das-americas/. O BREEAM Awards 2018 é concedido pela mais antiga empresa certificadora de construções sustentáveis no mundo, sediada em Londres.

${ }^{24}$ http://www.educafro.org.br/site/conheca-educafro/

25 http://www.sentimentanimalidades.net/pvnc/index.htm

${ }^{26}$ Em 2016, em todo país contavam-se 27 os cursos de licenciatura indígena. Além do já generalizado ingresso por cotas (5\% para índios), sete universidades públicas (1 estadual) adotaram o "vestibular indígena", um processo seletivo direcionado. 
ações afirmativas (política de cotas e de permanência), exemplos que são conquistas do movimento índio, sendo, portanto, cursos e políticas pensadas e elaboradas "com" e não "para" os povos indígenas.

Para além do esforço de inclusão indígena nas IES, também existe uma ampla construção de experiências de educação indígena em todos os níveis, especialmente a da escola indígena bilíngue e intercultural, valorizadora da experiência de cada povo, diferenciada daquela que negou e silenciou suas culturas. Foi o advento desta escola indígena que trouxe a demanda de formação dos professores índios, ator decisivo neste processo de mudança da escola colonialista. Na luta pelos direitos indígenas e fortalecimento de suas culturas, a educação tem enorme relevância, sendo a mesma fundamental na construção de relações póscoloniais $^{27}$. A educação indígena contribui imensamente para "reenraizar os jovens em suas culturas tradicionais", retomando tradições "por anos reprimidas pelo ensino oficial" (Lisboa, 2017: 239; 247). Mais que de programas de acesso as IES, aqui se buscam formas pedagógicas adequadas; usar seus idiomas; elaborar materiais didáticos culturalmente corretos; promover valores e conhecimentos não eurocêntricos. Ou seja, tratam-se de programas que ambicionam a construção de uma outra universidade, intercultural.

Outra valiosa ação educativa includente é o projeto "Novos Caminhos" ${ }^{28}$, voltado para a formação profissional e inserção no mundo do trabalho dos adolescentes abrigados em Programas de Acolhimento que não tem perspectivas de retornar à família ou de serem adotados. Como o acolhimento nestes programas encerra-se ao completarem 18 anos, urge prepara-los para o exercício da autonomia. Buscando isto, uma parceria entre o Tribunal de Justiça de Santa Catarina, a Associação dos Magistrados Catarinenses, e a Federação das Indústrias do Estado de Santa Catarina implantou em 2013 o Novos Caminhos, oferecendo aos jovens abrigados a partir dos 14 anos cursos profissionalizantes e outras atividades complementares visando a sua qualificação e encaminhamento para o trabalho.

Ainda na área do acesso à educação, vale salientar o "F123"29. Criado em 2010 por Fernando Botelho (SP, 1968), trata-se de empreendimento social que oferece um software

\footnotetext{
A Universidade Federal de Roraima é a única que conta com um instituto de formação superior indígena, o "Insikiran" (http://ufrr.br/insikiran/), que oferece três cursos de formação em nível de graduação para povos tradicionais, além das vagas nos demais cursos.

Cabe também realçar o "Rede de saberes", um programa de permanência de indígenas no ensino superior da Universidade Católica Dom Bosco (UCDB/MS), financiado pela Fundação Ford e reunindo parcerias entre a UCDB, UEMS, UFGD e UFMS, que desde 2005 apoia a trajetória dos acadêmicos indígenas dentro das IES.

${ }^{27}$ No dizer do moicano Taiaiake Alfred, intelectual indígena canadense, "a educação é o caminho para o conhecimento, a arma que nossos guerreiros precisam no século XXI. Enfrentar o Estado sem uma educação hoje seria como entrar em uma batalha contra a cavalaria com arco e flechas" (apud Lisboa, 2017: 239).

${ }^{28} \mathrm{http}$ ://amc.org.br/novoscaminhos/programa-novos-caminhos/

${ }^{29}$ https://f123.org/
} 
barato ( $8 \%$ do preço do convencional), cursos online e de serviços de consultoria em três idiomas para a inclusão de cegos ou pessoas com deficiência visual, com usuários em mais de 20 países.

Também não poderíamos deixar de mencionar a “4you2”, startup que democratizou o ensino de inglês oferecendo cursos baratos (reduz em até 1/7 o custo) nas periferias de São Paulo, Minas Gerais e Paraíba. Fundada pelo estudante Gustavo Fuga (RJ, 1993) em 2011, ela oferece não apenas o ensino de idiomas, mas experiências transculturais acessíveis e de qualidade para a base da pirâmide social, uma vez que todos os professores são estrangeiros (intercambistas ou profissionais refugiados), provenientes de 40 países, que moram com uma família na comunidade em que lecionam. Com turmas de no máximo 15 alunos, por suas salas já passaram mais de $10 \mathrm{mil}^{30}$.

8) A tradicional cultura do bambu é aperfeiçoada e difundida ainda mais através das bambuzerias, entre as quais desponta a "CERBAMBU - Centro de Referência do Bambu e das Tecnologias Sociais”, em Ravena/MG ${ }^{31}$, tocada por Lúcio Ventania (MG, 1966), um dos principais representantes da qualificação e popularização do uso do bambu no Brasil. É um típico inovador brasileiro que integra tecnologia, design e sociedade com seu talento de perceber espaços e recriá-los como oportunidades sustentáveis. Sua versatilidade (múltiplos usos) - construção civil, artesanato, moveis, alimentação, medicina, vestuário, decoração, utilitários, brinquedos, proteção ambiental ... - e demais características - leveza, flexibilidade, resistência, renovabilidade, durabilidade (quando tratado), abundancia, gratuidade, rapidez (de crescimento - altíssima produtividade), moldabilidade, beleza, sustentabilidade (não gera

\footnotetext{
${ }^{30}$ Como muito jovem empreendedor, Gustavo quer fazer a diferença e espalhar conhecimento: "Dinheiro é consequência, mas não é objetivo final, não é isso que motiva a gente. A gente quer ver as coisas diferentes. Eu quero ver o mundo diferente quando eu morrer. Não quero deixar o mundo igual, não vim pra Terra pra isso" (http://g1.globo.com/economia/pme/pequenas-empresas-grandes-negocios/noticia/2017/12/startup-oferececursos-de-ingles-em-comunidades-precos-acessiveis.html).

Vale transcrever o Manifesto da You2:

"Somos mais que uma escola de inglês. Somos encurtadores de fronteiras. Construímos pontes entre você e o mundo. Somos apaixonados por ideias. Somos loucos por criatividade. Somos ávidos por INOVAÇÃO. O que nos dá brilho no olho é trazer para a sala de aula uma amostra do mundo que gostaríamos de viver: um lugar de debate (e menos imposições), diverso e que todos aprendam continuamente. Queremos criar conexões verdadeiras. Não ensinamos: construímos e produzimos conhecimento em conjunto. Aqui não tem espaço para preconceito: somos extremamente comprometidos com o conceito de diversidade cultural. PROVAMOS TODOS OS DIAS QUE O MUNDO É MUITO MAIOR DO QUE VOCÊ OUSA PENSAR. Vamos além: cuidamos da sua desenvoltura no idioma, mas cuidamos também do seu crescimento cultural. E nos orgulhamos disso. Acreditamos em relações transparentes, sem letras pequenas. Trabalhamos diariamente para sermos uma organização humanizada e que realmente se importa com você, com seu tempo e com sua rotina. PENSAMOS GRANDE, PENSAMOS GLOBAL. Por isso temos como bandeira a democratização e o acesso à educação. Idealistas e megalomaníacos? SIM, mas com profundo senso de qualidade e respeito ao aluno. Queremos mudar a sociedade. Mas, principalmente, queremos que todos façam parte dessa MUDANÇA: que ela seja de baixo pra cima e que ela seja pra você também." https://4y2.org/pt/home-page/

${ }^{31} \mathrm{http}: / / \mathrm{www}$. cerbambu.org.br/
} 
impacto ambiental, ao contrário: é utilizado para evitar a degradação de solos e para absorver carbono) - o bambu é, literalmente, uma planta de mil utilidades e única em todo universo, apta a gerar uma potente cadeia produtiva inclusiva (não há barreiras de capital no seu uso: em geral bastam ferramentas simples, como canivete, trabalhando-se artesanalmente, sendo suas técnicas de domínio público) e um novo e ecológico ciclo econômico de prosperidade limpa, leve e bela.

9) Dentre as incontáveis experiências de reciclagem de resíduos, releva-se a "Associação dos Catadores de Papel, Papelão e Material Reaproveitável (ASMARE)"32. Fundada em 1990, culminação do esforço da Pastoral de Rua da Arquidiocese de Belo Horizonte com um dos segmentos mais excluídos da sociedade, a ASMARE vem, através de parcerias com a Prefeitura, inserindo progressivamente o catador no mercado da reciclagem por meio de coleta seletiva. Reciclando vidas e sonhos, sua fundadora, Maria das Graças Marçal (MG, 1950), conhecida como Dona Geralda, ganhou em 1999 prêmio da UNESCO para quem se destacou em projetos de alcance social, e foi eleita pela revista Claudia, em 2009, uma das cinco mulheres do ano.

10) Finalmente, incidindo na linha de negócios inclusivos com intenso uso de TI, cabe registrar os seguintes casos e organizações brasileiras que nela se inserem e estão a difundi-la:

“ARTEMISIA": organização fundada em 2004 para apoiar empreendedores que querem transformar o Brasil com negócios lucrativos que incluam pessoas de baixa renda ${ }^{33}$. Buscando oferecer "soluções escaláveis para problemas sociais da população de baixa renda", entende ser parte de sua missão "criar uma nova geração de negócios que rompam com os padrões precedentes e (re)signifiquem o verdadeiro papel que os negócios podem ter na construção de um país com iguais oportunidades para todos". Seu "Manifesto" explicita que

"Entre ganhar dinheiro e fazer a diferença, escolhemos ficar com os dois. (...) Integrar
negócios e impacto social é nossa crença fundamental. (...) Estamos construindo uma
nova geração de negócios para resolver os dois lados de uma mesma questão. E porque
queremos construir os negócios do futuro, não temos medo de assumir riscos para
romper com padrões e transformar o que já não pode mais seguir como está. (...) E,
acima de tudo, cuidaremos para (...) garantir a construção de negócios que
genuinamente melhorem a vida de centenas, milhares, milhões ou até mesmo bilhões
de pessoas"34.

"Escola Popular de Comunicação Crítica (ESPOCC)": criada em 2005 pelo "Observatório de Favelas", no conjunto de favelas da Maré (RJ), a ESPOCC busca introduzir jovens e adultos das periferias no campo da comunicação, visando potencializar sua ação crítica e transformadora. Para tal trabalha com linguagens e técnicas da "Publicidade Afirmativa", a

\footnotetext{
${ }^{32}$ http://asmare.org/

${ }^{33} \mathrm{http}$ ://artemisia.org.br/conteudo/artemisia/o-que-fazemos.aspx

${ }^{34} \underline{\mathrm{http}}$ ://artemisia.org.br/conteudo/artemisia/nosso-manifesto.aspx
} 
qual não visa fins estritamente comerciais pois promove valores de sociabilidade, a cultura e o empreendedorismo comunitário e socioambiental ${ }^{35}$.

"Gastromotiva": "Não basta a comida ser boa, ela precisa também fazer bem para a sociedade". Trabalhando com o conceito de gastronomia social, ou seja, a comida como agente de transformação, a Gastromotiva é uma organização que busca transformar a vida de pessoas em vulnerabilidade social através da comida, oferecendo, para tal, cursos de cozinha e outras atividades. Iniciada em 2006 pelo chef David Hertz (PR, 1974), e aproveitando sobras não comercializáveis em ceasas, feiras e supermercados, ela usa a gastronomia como ferramenta promotora de educação, empregabilidade e renda, tendo a colaboração de renomados chefs, tais como Alex Atala (SP, 1968), o qual ministrou cursos junto ao projeto "Gastronomia nos Presídios", entre outros. Sua filosofia é: "Não basta apenas ensinar a cozinhar. Queremos formar cidadãos mais conscientes e preparados para o mercado de trabalho. Contribuindo com seu crescimento pessoal, profissional e também das comunidades onde vivem" 36 .

"BlackRocks": iniciativa de Maitê Lourenço (SP, 1984) que, considerando que a maioria dos microempreendedores do Brasil é negra, tem por missão

[...] aumentar a diversidade racial no ecossistema empreendedor brasileiro com o apoio a profissionais - negras e negros - para atuarem como executivos, programadores/desenvolvedores em empresas de tecnologia e/ou como fundadores de startups inovadoras. ${ }^{37}$;

"Protagonizo": plataforma que visa ampliar a presença de afrodescendentes nas grandes empresas, criada por Alexandra Loras (França, 1977). Com a filosofia de que "a diversidade é boa para os negócios", pois "pesquisas apontam que empresas com diversidade étnico-racial aumentam a rentabilidade de $35 \%$ a $40 \% "$, ela atua especialmente junto aos departamentos de recursos humanos das grandes empresas, quebrando preconceitos presentes nestes setores e aproximando-os de talentos negros poliglotas egressos de renomadas universidades ${ }^{38}$.

“EMPREGUEAFRO”: Fundada por Patrícia Santos de Jesus em 2004 e também com a metodologia de aliar os recrutadores e profissionais de RH ao processo de inclusão, ela diz que $90 \%$ das empresas que buscam seus serviços são americanas, onde há negros no alto escalão. "Quando eles visitam o Brasil, não entendem como 50\% da população é negra mas não

\footnotetext{
${ }^{35} \mathrm{http}$ ://www.espocc.org.br/a-espocc/como-funciona/

${ }^{36} \mathrm{http}: / / \mathrm{www}$. gastromotiva.org/pb/

${ }^{37} \mathrm{http} / / / \mathrm{www} \cdot$ blackrocks.com.br/\#nossa-missao

${ }^{38}$ http://www.protagonizo.com/hotsite/
} 
é representada na empresa, e começam a fazer pressão." ${ }^{39}$ Hoje entre as 150 maiores empresas do país, $20 \%$ estão em sua carteira de clientes.

Recentemente uma notícia extraordinária ${ }^{40}$ desvelou que, na contramão da retração econômica e descenso social ocorrida generalizadamente no ano de 2017, 464 mil negros e pardos ascenderam para as classes A e B. Com exceção da classe mais pobre, todas as faixas sociais tiveram redução. 800 mil pessoas deixaram as classes mais altas. Apesar desta diminuição, a participação da "população de cor" ampliou-se. Tal fato excepcional não é explicável por um único fator, e sim por inúmeros, inclusive a recente política pública de ações afirmativas e cotas étnico-raciais. Todavia, como esta ainda começa a produzir seus primeiros frutos, ela pouco explica a escala ocorrida (quase 500 mil pessoas) de inserção nas faixas de mais alta renda.

Tal fenômeno representa uma mudança cultural e econômica profunda, para a qual, sem dúvida, contribuiu a "militância negra" contra o racismo e em prol da sua afirmação identitária. Mas, dentro deste pano de fundo, tal tipo de ascensão, e na amplitude posta, se opera e efetiva através de um amplo e meticuloso trabalho duma miríade de organizações fomentando o empreendedorismo e a inclusão dos afrodescendentes, como as dos últimos casos acima, e também aquelas vistas nos tópicos 1 e 7. Configurando um padrão bottom-up (processos advindos de baixo) aberto e emergente, elas tiveram um protagonismo fundamental. Até por ocorrer na contramão dum processo recessivo, e também se sustentar em elevações na produtividade conectadas com os novos metabolismos econômicos da terceira revolução industrial, estamos diante de um tipo de inclusão que promete ser duradouro. Isto se diferencia profundamente da frágil inclusão dos mais pobres apenas pelo consumo advindo de transferências diretas e facilidades creditícias recentemente ocorrida com as políticas socioeconômicas petistas, e que rapidamente estancou e até retrocedeu. Talvez esteja em curso um verdadeiro fim da eterna sujeição e subalternidade de nosso povo, como examinaremos a seguir.

\section{DESCOLONIZAÇÃO, PARTE SEGUNDA}

"Querer apegar-se à tradição ou reatualizar as tradições abandonadas é ir não somente contra a história, mas contra seu próprio povo" (Fanon).

\footnotetext{
${ }^{39}$ https://www.valor.com.br/carreira/5016362/recrutadoras-especializadas-em-inclusao-racial-ganhamespaco-entre-multis. Mais informações em: https://empregueafro.com.br/wp/
}

40 https://www1.folha.uol.com.br/mercado/2018/08/em-retracao-classes-a-e-b-ganham-464-mil-negros.shtml 
"Os processos são os devires, e estes não se julgam pelo resultado que os findaria, mas pela qualidade de seus cursos e pela potência de sua continuação" (Deleuze).

Leilas e Zicas; Celsos e Adalbertos; Joaquins e Baniwas; Lúcios e Geraldas; Davis e Fernandos. Além destes personagens que estão a moldar o seculo XXI, existem inúmeros "heróis anônimos" que (re)constroem este imenso país aproveitando de pequenas brechas e oportunidades, configurando milhões de empreendedores a formar um gigantesco tsunami econômico e uma autêntica "metamorfose", superiora as mega e midiáticas "revoluções" conduzidas por super-heróis ${ }^{41}$.

A amplitude da riqueza advinda das inovações institucionais, tecnologias sociais, invenções democráticas e negócios inclusivos forjadas no Brasil é incomensurável e ultrapassa qualquer tentativa de contabilizá-las e descreve-las. Para além das já arroladas, deparamo-nos ainda com uma infinidade de bem sucedidas práticas, seja em outros setores e redes (como as da justiça reparativa; da permacultura e da educação biocêntrica ${ }^{42}$ ), seja provinda de lutas e organizações (como o movimento da biciletada; a experiência metodológica do "MOC Movimento de Organização Comunitária"43; ou da "Rede Brasileira de Incubadoras de Cooperativas Populares").

\footnotetext{
${ }^{41}$ Uma pequena amostra destes notáveis anônimos são os agraciados em 2017 com o "Prêmio Veja-se", o qual honrou cidadãos que, longe dos holofotes, são agentes de transformação da sociedade brasileira: Roberto Nogueira (Brisanet); Joice Toyota (Vetor Brasil); Flávia Rezek (Escola Municipal Rio de Janeiro, na Favela do Jacaré); Priscila Miranda (Associação Presente); Maitê Lourenço (BlackRocks); Sylvia Guimarães (Associação Vagalume).

${ }^{42} \mathrm{http}: / /$ www.pensamentobiocentrico.com.br/content/ed06 art01.php; http://biodanca.blogspot.com.br/2007/08/educao-biocntrica-teoria.html .

A Educação Biocêntrica, mais conhecida como "Biodança", é outro fenômeno que tem na capital cearense um dos seus principais polos de difusão no Brasil, mesmo não tendo nela surgido. Mas, como vimos, em Fortaleza nascem: os movimentos da Farmácia Comunitária; Terapia Comunitária; Parto Natural, e o Banco Palmas, a mais exitosa experiência da economia solidária brasileira (o que não é pouco pois muito tem surgido neste campo). Cabe incluir ainda sua condição de polo de desenvolvimento da rede de jangadas.

Como explicar a exuberância deste conjunto de afloramentos que brotam em Fortaleza e se espalha pelo mundo? Sendo uma das principais metrópoles do norte/nordeste brasileiro, para ela converge uma forte corrente migratória de todo sertão e do seu imenso litoral, sendo, portanto, espaço de expressão de inúmeros elementos de um Brasil profundo. Nesta metrópole dá-se uma confluência de processos que possibilitam o surgimento de movimentos singulares, impulsionado por um amplo dinamismo popular. O Banco Palmas, por exemplo - com a liderança de Joaquim Melo Neto, ex-seminarista - e a organização popular do bairro Palmeira é fruto de todos estes processos/encontros.

Como um autêntico território dissidente, Fortaleza revela-se um caldeirão onde fermentam inúmeras "invenções democráticas" (tecnologias sociais). Para este aflorar a Universidade Federal do Ceará é um relevante ponto de apoio, comportando-se como uma instituição em que muitos ingredientes que gestam estas alternativas populares são cozidos. Desde os 70, a capital cearense também foi uma das regiões onde as práticas da Teologia da Libertação mais se desenvolveram, com o respaldo do cardeal Aloísio Lorscheider. Nela ainda hoje vivem dois grandes pensadores vinculados à TdL, o prof. pe. Manfredo de Oliveira (um dos principais filósofos brasileiros) e Eduardo Hoornaert.

${ }^{43}$ O MOC (http://www.moc.org.br/) é liderado por Abdalaziz de Moura (PE, 1944), também fundador do Serta Serviço de Tecnologia Alternativa (http://www.serta.org.br/index.php). Em 2017 foi um dos premiados na 11
} 
Contra tudo e contra todos, todavia, esta força que se faz cada vez mais presente no cenário brasileiro contemporâneo, moldando-o decisivamente, emerge num processo praticamente auto-espontâneo e completamente descentralizado, superando seculares barreiras de preconceito, classe e geografia.

\section{Enquanto isto, mais desenvolvimentismo: apadrinhando as campeãs da nação.}

"Se a Copa do Mundo era para ter sido a apoteose do projeto do Brasil Grande lulista, o 7 a 1 é o seu supremo anticlímax" (Moysés Pinto Neto).

Os recentes governos petistas (14 anos contínuos no plano federal, e diversos outros a nível estadual e municipal), apesar de contar com amplo respaldo desta base popular, inclusive como parte dos seus quadros de militância partidária, não tiveram coragem - ou capacidade de construir e mostrar ao mundo um caminho alternativo à rota ocidental de desenvolvimento (uso intensivo de capital e energia; produção em grande escala e culto ao gigantismo; dinâmica de extroversão - voltado para além das fronteiras, com traços imperialistas - subordinação das maiorias, passiva, depreciativa e folcloricamente consideradas; e indiferença para com a exploração abusiva dos "recursos naturais"). Ao contrário, optaram descarada e interesseiramente por tocar grandes obras com as maiores empreiteiras deste país de forma a asfaltar (literalmente, inclusive retomando antigas ideias da ditadura militar de cortar a Amazônia com estradas e imensas hidrelétricas) o caminho para tornar o Brasil, gigante por natureza, um gigante econômico e político de fato.

Estas grandes obras se ergueram especialmente em torno do "PAC, Programa de Aceleração do Crescimento", sua principal política econômica, de corte desenvolvimentista. Fiel ao lema positivista e decimonômico 44 "Ordem e Progresso", reabilitaram em pleno século XXI o então ultrapassado ideário do "crescimento econômico", acelerando-o e assim escancarando um debochado retrocesso frente a internacionalmente consagrada ideia de que "desenvolvimento" significa muito mais que mero crescimento. Para acalmar e manter sob controle a militância, políticas residuais foram destinadas para apoiar estes setores populares, de resultados em geral pífios, mas com o efeito simbólico de edulcorar com autenticas “cerejas" o bolo desenvolvimentista.

A aliança petista pôs em curso um projeto neo-desenvolvimentista caracterizado por consolidar oligopólios privados sob patronato estatal, buscando constituir global players

edição do prêmio Trip Transformadores. Ainda sobre Moura: http://www.cartacapital.com.br/sociedade/o-mel-ascabras-a-farinha-e-a-avo.

${ }^{44}$ Relativo ao século XIX. 
"brasileiros". No padrão nacional-desenvolvimentista anterior, iniciado com Getúlio Vargas, investimentos públicos formaram grandes empresas estatais (CSN, Vale do Rio Doce, Petrobras, Eletrobrás, Telebrás). O desenvolvimentismo petista visou fortalecer o grande capital privado. Agora, o Estado, especialmente através do BNDES (o maior banco de fomento do mundo), é a principal alavanca para criar gigantes privados, verdadeiras multinacionais brasileiras, para terem capacidade de competir no mercado internacional, reestruturando o capitalismo brasileiro. Luciano Coutinho, então presidente do BNDES, justificava que "empresas brasileiras competentes e competitivas devem merecer o apoio do BNDES para se afirmarem internacionalmente" (...) "todas as economias desenvolvidas têm empresas transnacionais" 45 .

Frustrando a expectativa de que Lula refundaria o Brasil, pois representava uma longa caminhada dos movimentos sociais (sindical, popular, pastoral), o maior avanço de seu governo foi juntar uma pitada de política social com a ortodoxia econômica. Apesar disto dar continuidade, em linhas gerais, aos dois mandatos do governo anterior de Fernando Henrique Cardoso, acabou sendo saudado como "pós-Consenso de Washington". Nestes anos de governo do PT esta perspectiva desenvolvimentista (grandes projetos, rodoviarismo, prioridade na aliança com os grandes capitais ...) seguiu completamente hegemônica e praticamente sem resistências. Lembrando que o BNDES lida com recursos dos trabalhadores, a crítica mais comum questionava a política de "escolher os vencedores da economia" e subsidiar negócios que geram poucos empregos e elevam a concentração de mercado.

As cidades pioraram muito e vão piorar mais, não por ausência de planejamento urbano e leis. Elas se inviabilizam por um problema estrutural: são construídas para servir ao automóvel, lembrou Ermínia Maricato (2010). Os recentes incentivos para a indústria automotiva (como a desoneração fiscal para compra de automóveis e subsídios para a aquisição de caminhões à diesel - erro duplo: caminhões e diesel) levaram a dobrar o número de automóveis em circulação entre 2003 e 2014, e a expandir significativamente a já ampla frota de caminhões, ampliando a irracionalidade e o caos nas cidades e rodovias. Ao invés de desenvolver outros modais (ferroviário, aquático ou mesmo tubulações para escoamento de combustível) - mais compatíveis com seu imenso litoral e a maior rede hidroviária do mundo - o aprofundamento da custosa e fatal opção rodoviarista vai na contramão do futuro cada vez mais pautado por energias não fósseis e renováveis. Outra trágica sequela do rodoviarismo é

\footnotetext{
${ }^{45}$ https://www.ecodebate.com.br/2009/11/14/conjuntura-da-semana-especial-a-reorganizacao-do-capitalismobrasileiro/
} 
ele ser um dos maiores fatores do alto "custo Brasil", limitando e empobrecendo nossa economia.

Além da opção pela Copa e Olimpíadas ${ }^{46}$, cabe arrolar também entre os mais emblemáticos feitos do lulismo as devastadoras grandes hidrelétricas na Amazônia (Santo Antonio, Girau, Belo Monte, Teles Pires) - obras que nem a ditadura militar conseguiu implantar ... - e a controversa e ineficaz transposição do São Francisco, opções que se explicam mais pelas vultuosas propinas e caixa dois, pois, do ponto de vista da eficiência econômica são projetos duvidosos e polêmicos. A implementação disto tudo ocorreu inclusive usando força policial, atropelando amplos movimentos populares (originalmente também constitutivos da base social petista) que resistiam e apontavam alternativas. Particularmente na transposição do São Francisco, a ASA (Articulação do Semi-Árido) liderou uma imensa concertação de entidades que combateu o privilegiamento do uso econômico desta água em detrimento da propaganda oficial que apregoava sua destinação aos mais carentes. A proposta popular buscava também a revitalização do São Francisco; defendia um projeto alternativo de abastecimento de caráter mais difuso e dinamizador de clusters produtivos (redes econômicas locais); atendia uma população quase quatro vezes maior e deveras necessitada; e pela metade do preço da transposição ${ }^{47}$.

$\mathrm{Na}$ contramão da opção dos governos do PT pelo grande capital ${ }^{48}$, à medida em que o século XXI avança se consolida a irrupção vulcânica da fantástica criatividade que brota da imensa maioria dos outrora condenados da terra. Esta eclosão revela o desabrochar de um Brasil includente, liderado por mulheres, com forte presença negra e intenso protagonismo camponês, indígena e dos pequenos empreendedores. Um Brasil onde Anitas ${ }^{49}$ não mais assujeitadas

\footnotetext{
${ }^{46}$ Durante a ditadura, João Havelange, então presidente da Fifa, procurou seu amigo, o presidente João Figueiredo, e lhe propôs realizar a Copa do Mundo no Brasil. Com extrema lucidez, Figueiredo the respondeu: "Você já viu uma favela no Rio de Janeiro ou uma seca no Nordeste? Acha que eu vou gastar dinheiro com estádio de futebol?" (https://oglobo.globo.com/opiniao/figueiredo-estava-certo-12799581).

${ }^{47} \mathrm{http}: / /$ reporterbrasil.org.br/2006/12/750-organizacoes-do-semi-arido-dizem-nao-a-transposicao/; http://www.ihu.unisinos.br/78-noticias/566590-a-transposicao-do-rio-sao-francisco-aguas-e-falacias-dodesenvolvimento

${ }^{48}$ Um conjunto significativo de autores comprometidos com o "poder social" e transformações práticas desde abaixo não se intimida em criticar as insuficiências e contradições não apenas da era petista e sua "hegemonia às avessas", mas também do recente ciclo de governos progressistas na América Latina, entre os quais: Alberto Acosta; Cesar Benjamin; Eduardo Gudynas, Francisco de Oliveira; Gustavo Esteva; Leda Paulani; Maristella Svampa; Raul Zibech e Rui Braga. Destaco em particular as seguintes obras: "Cinco mil dias. O Brasil na era do lulismo" (Boitempo, 2017); "Descolonizar o imaginário" (Elefante, 2016); Fábio Santos: “Além do PT" (Elefante, 2016); Svampa: "Debates latinoamericanos" (Edhsa, 2016); "Hegemonia às avessas" (Boitempo, 2010); José S. Martins: "Do PT das lutas sociais ao PT do poder" (Contexto, 2016); Raquel Rolnik: "Guerra dos lugares" (Boitempo, 2015); Fábio Zanini: "Euforia e fracasso do Brasil grande" (Contexto, 2017).

${ }^{49}$ Refiro-me ao maior e mais arrebatador fenômeno pop brasileiro em termos de repercussão mundial, o videoclipe "Vai, malandra" com o funk feminino da cantora e compositora Anitta (RJ, 1993). Em março de 2018 ela foi uma das vencedoras do iHeartRadio Music Awards, o qual elege os destaques da música nas rádios dos Estados Unidos.
} 
buscam ganhar "dinheiro e projeção com seus corpos, no comando da própria monetização de suas vidas“ (Bentes, 2017). Passo a passo, a carne negra deixa de ser a mais barata no mercado. A natural busca por melhorias vai deixando de ser inibida por relações sociais desfavoráveis e ideologias maniqueias.

Por outro lado, as tecnologias de comunicação eliminam barreiras para que pessoas "comuns" se posicionem como referências relevantes em determinados setores, gerando uma caótica e explosiva manifestação de diversidade que pulveriza centralismos e comandos hierárquicos. Exemplo disto é o fenômeno dos youtubers (pessoas populares no YouTube) que viralizam e se tornam rápida - e muitas vezes efemeramente - fenômenos de massa.

Na mesma medida em que as instancias político/institucionais se encolhem e paralisam, pois se distanciam cada vez mais de cumprir seu papel para a provisão daquilo que é indispensável para a vida comum (saneamento, educação, segurança, mobilidade), a participação da sociedade e suas redes conquista um espaço cada vez maior. Progressivamente vemos " $n$ " sinais de que frações substantivas do nosso povo, historicamente oprimidas e ignoradas, começam a sair da sua condição de minoridade intelectual, social e política. Aos poucos a Constituição-Cidadã de 1988 começa a frutificar, especialmente no que tange ao reconhecimento dos povos indígenas. E a resultante da controversa política de cotas também promete uma grande colheita.

\section{ETNOGÊNESE: A REVERSÃO DO PROCESSO COLONIAL}

$$
\begin{array}{r}
\text { "A identidade de um povo não deve buscar-se na originalidade de seus traços culturais, mas na } \\
\text { capacidade deste povo de gerar sentidos sociais e políticos que o unificam na luta por definir sua razão de ser } \\
\text { como povo" (Carlos Zambrano). }
\end{array}
$$

\footnotetext{
"Quando se trata dos europeus, chamamos este processo de Renascimento. Quando se trata dos outros, chamamos de invenção da tradição, um signo de decadência cultural que produz apenas simulacros de um passado morto" (Marshall Sahlins).
}

Aquela premiação de uma construção inspirada nas técnicas indígenas (tópico 6) é reveladora do quanto ainda temos por descobrir e reconhecer quanto à positividade da contribuição das sociedades "primitivas", as quais, no dizer de Pierre Clastres (1978: 139), "não são embriões retardatários das sociedades ulteriores ... não se encontram no ponto de partida de uma lógica histórica que conduz diretamente ao termo inscrito de antemão".

Esta ruptura com o tempo linear e seu decorrente evolucionismo foi antecipada por Oswald de Andrade, que, quebrando com o espelho europeu e subvertendo com sua antropofagia a imagem do primitivo como inferior, há quase um século, partindo do pressuposto 
de que "a alegria é a prova dos nove", revelou uma sociedade caraíba "sem complexos, sem loucura, sem prostituições e sem penitenciárias" (1990: 51-52).

Apesar de Oswald e Clastres, o processo de descolonização muito tardou, e somente no século XXI começa a decolar com mais vigor, agora pelo próprio protagonismo indígena e popular, enfrentando grandes resistências e fortes preconceitos. Paulatinamente os povos nativos vão rompendo a teia colonial europeia que os envolveu e degradou como inferiores e subalternos, desnudando a armadilha da "ilusão de primitivismo" que os encobre, pois demonstram que a sua presença não significa "empecilho para o progresso". No dizer de Manuela Carneiro da Cunha (1992: 22),

[...] durante quase cinco séculos, os índios foram pensados como seres efêmeros, em transição: transição para a cristandade, a civilização, a assimilação, o desaparecimento. Hoje se sabe que as sociedades indígenas são parte de nosso futuro e não só de nosso passado.

Manuela captou isto na aurora do movimento indígena contemporâneo (que irrompe no final dos anos 70). Todavia, Darcy Ribeiro, em que pese seu hercúleo esforço em salvar os "remanescentes" indígenas, literalmente, por estar visceralmente agarrado à tese da mestiçagem, não entendeu o significado dos povos silvícolas para a civilização brasileira, e não acompanhou Manuela neste diagnóstico. No que tange à temática indígena, Darcy foi ultrapassado pelos fatos, ou seja, pelo levante indígena hodierno. A seguinte percepção de Viveiros de Castro bem desvela os limites darcisistas:

Nas últimas décadas tem acontecido no Brasil algo inverso ao problema que ocupava os fundadores da sociologia do contato. Em vez de os índios se tornarem, aos poucos, brasileiros, são os brasileiros que estão virando índios. ${ }^{50}$

Uma "cegueira ontológica" (Bartolomé, 2006: 201) cristalizada em conceitos estatísticos e censos demográficos gerou um "etnocídio estatístico" (Bonfil Batalla, 1981: 21) que invisibilizou e subestimou tanto o indígena quanto o rural. A ficção oficial superdimensionou o urbano, classificando como cidades todas as sedes municipais: até tribos indígenas são consideradas centros urbanos, alertou José Eli da Veiga (2002). O processo colonial etnocida levou as identidades indígenas e camponesas a se sobreporem por longo tempo - configurando populações “campesíndias”, vislumbrou Armando Bartra (2008: 181).

Aos poucos, um processo reverso leva a reemergir grupos étnicos que se identificam como "originários" (fenômeno denominado de "etnogênese"), bem como um revigoramento do campesinato conjugado com dinâmicas de recampesinação - vide a consolidação das cada vez

\footnotetext{
${ }^{50}$ https://umaincertaantropologia.org/2014/01/06/o-antropologo-contra-o-estado-piaui/
} 
mais vigorosas redes de agroecologia (tópico 4) ${ }^{51}$. Isto é surpreendente e aparentemente anacrônico, pois vai na contracorrente da ainda hegemônica visão urbanista e industrializante que conduz o "projeto nacional”. Talvez sejam sinais de uma profunda transição civilizatória, como já indiquei em outro lugar ${ }^{52}$. As facilidades comunicacionais advindas novas formas tecnológicas diluem o clássico antagonismo rural-urbano característico da modernidade eurocentrada, difundindo dinâmicas "rurbanas" e "pós-tradicionais" que não mais opõem o rural ao urbano, mas combinam fortemente seus elementos, permitindo sermos "rurais" na cidade e "urbanos" no campo (Carneiro, 1998), tal como na profecia das cidades-jardins de Ebenezer Howard $^{53}$. A reaproximação das cidades para com o rural e o indígena, uma vez que estes deixem de ser despossuídos, poderá reverter e sanar o atual cenário colonial-metropolitano de medo e violência entre a crescente, envolvente e segregada periferia e os centros urbanos, degradador de qualquer perspectiva de urbanidade e civilidade.

A dispersão produtiva global no mundo das redes, e a profusão de inovação que dele jorra e que ultrapassa qualquer tentativa de enquadramento e controle (as quais simplesmente a castram), conjugada com o advento da perspectiva ecológica da vida e o reconhecimento de

\footnotetext{
${ }^{51}$ Para um aprofundamento sobre os processos de recampesinação consultar as obras de Eric Sabourin, Jan van der Ploeg, Dominique Temple, Manuel Toledo, Joan Martínez Alier, Maria Ignez Paulilo, Marilda Menezes, Sérgio Schneider, Armando Bartra e Ricardo Abramovay. Para a compreensão da etnogênese contemporânea os já citados Bonfil Batalla, Bartolomé, Viveiros de Castro e Carneiro da Cunha são centrais.

52 "Os campesíndios, aproximadamente a maioria da humanidade, estão fora do lugar dentro da sociedade moderna, a qual gerou uma enferma assimetria campo-cidade, em detrimento do campo - outra ferida que retrata a colonialidade gerada pela epistemologia-ontologia moderna. Por assumir um papel protagônico dentro das novas formas de economia ecológica, por aportarem elementos valiosos na construção de uma economia para a vida, a "iletrada" comunidade campesíndia está a desafiar epistemológica, política e economicamente a hegemonia do sujeito moderno (solipsimista, urbano, branco, masculino e escolarizado). Do mundo camponês e sua multifuncionalidade desponta - com a agricultura familiar, agricultura orgânica e agroecológica, permacultura, reservas extrativistas, bambuzerias, e a reabilitação do conhecimento farmacológico tradicional - uma recuperação epistemológica de ontologias não ocidentais, outras formas de valorar, de se relacionar com a natureza, outras dinâmicas de poder" (Lisboa, 2014: 76).

${ }^{53}$ Sua obra "Garden cities of tomorrow" (1898) demonstrou que "não há somente duas alternativas, vida urbana ou vida rural. Existe uma terceira que assegura a combinação perfeita de todas as vantagens da mais intensa e ativa vida urbana, com toda beleza e prazeres do campo" (108). Tomando emprestado do socialismo sua concepção do esforço comum, e do liberalismo a preservação do auto-respeito e confiança em si mesmo, Howard elaborou um modelo que, "embora encoraje a iniciativa individual, permite a mais completa cooperação" (117).

Ao desenhar cidades-jardins, enfatizando a interpenetração entre campo e cidade, Howard foi o grande impulsionador das alternativas urbanas experimentadas no século XX (na cidade de São Paulo, por exemplo, a região de maior área verde, os "Jardins" - Jardim América, Pacaembu, Morumbi... - origina-se de projetos urbanísticos do início do séc. XX inspirados diretamente em Howard). Howard foi precursor dos atuais movimentos de Reforma Urbana, Ecovilas, e Slow Cities.

Todavia, a proposta da cidade-jardim foi por muito tempo esquecida, predominando o ideário modernista a lá Corbusier, ou seja, a crença na racionalização do concreto e do automóvel divorciada dos aspectos socioambientais. As ideias de Howard foram esmagadas pela ação de duas febres que se viviam no alvorecer do séc. XX: a ideológica e a tecnológica. De um lado, a polarização ideológica entre comunistas e capitalistas; de outro, o encanto gerado pelo advento do automóvel e do elevador movido à eletricidade, impactando decisivamente a vida urbana, levando à verticalização das cidades e ao privilegiamento do transporte motorizado individual como forma de locomoção.
} 
que adentramos no antropoceno, desencantou o modelo fáustico de desenvolvimento e desvelou sua magia do progresso posta como corrida cega e confrontativa para o futuro. Não é suficiente que iluminados acessem os fundos públicos e detenham o mapa da mina para que este país vá para frente sem culpa e sem pecado, mesmo estando abaixo do Equador.

\section{DEVIR BRASIL: ULTRAPASSANDO OS PROJETOS CUPULISTAS DE NAÇÃO}

\footnotetext{
"Um povo se define pelo que quer vir a ser" (Cesar Benjamin).
}

Este novo mundo reticular torna ainda mais verídica tanto as proclamações de José Mariátegui, Homi Bhabha, Benedict Anderson e Ernest Renan de que nação é "alegoria”, "narração”, "invenção”, “comunidade imaginada”, "plebiscito diário”; quanto a denúncia de Samuel Johnson do apelo ao patriotismo ser "o último refúgio do canalha". O nacionalismo, ideologia que faz do "pertencimento a uma abstração coletivista - a nação - o valor supremo e a principal credencial de um indivíduo" (Vargas Lhosa, 2010: 231), é um imaginário útil às forças que se locupletam com o aparato do Estado, mas possui um caráter xenófobo e regressivo, pois impede aos povos perceberem os interesses comuns a toda humanidade e apenas amplia o fosso entre os mesmos, sem compreender que a própria identidade é um jogo de contrastes.

Por contraste, uma afirmação profética de Alceu Amoroso Lima, proferida em 1917, ajuda a compreender a grandeza das novidades em curso. Para Alceu, no Brasil "o século XVI pertenceu a Pernambuco, o XVII à Bahia, o XVIII a Minas Gerais, o XIX ao Rio de Janeiro, o século XX é o século de São Paulo" (apud Gonçalves, 2012: 176). Cem anos após, é difícil descortinar alguma hegemonia regional vigente neste novo milênio, e, sinceramente, não espero que o Sul, Brasília ou algum outro lócus a obtenha. Isto seria um grande desastre e um aprofundamento da secular sangria deste país a níveis insuportáveis. A aposta é que no sec. XXI não haverá mais centralidades (espacial/política) ou demiurgos salvadores, que o sec. XXI não será o da "hegemonia" de alguma vertente/região, mas da consagração do afloramento das diversidades compósitas do Brasil profundo.

A busca pela homogeneidade nacional sufoca as diferenças, excluindo a vital alteridade componente e definidora de qualquer perspectiva identitária. Hipostasiar ou fetichizar uma cultura, absolutizando-a e invocando uma pureza originária que nunca existiu, é catastrófico, pois gera incompreensões, obtusidades e barbarismos. O ser 
humano e os povos não se fundam somente no acervo de seu passado - senão as tradições ficariam mumificadas e intocadas - mas está em processo de permanentes intercâmbios e construção. Como seres orientados para o futuro, não estamos prisioneiros do passado, ainda que ele viva em nós, como canta Paulinho da Viola. "Se o homem é projeto, como diz Sartre, é o futuro que comanda as ações do presente", sentencia Milton Santos (1999: 265).

A afirmação identitária, especialmente quando negadora da pluralidade mutante que somos, ou seja, quando feita de forma monolítica, metafísica e estereotipada, carrega armadilhas e problemas, podendo dificultar, travar ou mesmo negar o elemento mais profundo do processo de descolonização: restaurar/reabilitar o humano. As próprias tradições histórico-culturais são inventadas e reinventadas permanentemente. Fixar-se em uma tradição é cair na armadilha etnofilosófica que essencializa a mesma, é amarrar nossos pés, mãos e pensamento, e nos deixar escravizar a deuses inimigos da liberdade impostos por nós mesmos.

Por um tempo demasiado, recorrentemente fomos possuídos pela ânsia da procura de uma "identidade brasileira", pela ideia da "formação nacional" em construção e que algum dia se completará. Ora, esclarece Paulo Arantes (1997: 12), este conceito de "nacional" é uma "noção normativa" que corresponde a um "ideal europeu de civilização". Com a chegada simultânea dos novos metabolismos econômico-planetários e da perspectiva pluriversal de existir - a aceitação das inúmeras formas e experiências de humanidade, a existência de modos diferenciados de ser - "não mudou apenas o caminho. Mudou a pedra". Ou seja, conforme enfatizará Marcos Nobre (2012), "já não é mais da 'formação da nação', com sua unidade e homogeneidade, que se trata”, pois o "processo de 'formação' se encerrou - ainda que não tenha se completado".

Fixado na construção da nacionalidade, hoje o "paradigma da formação" está "obsoleto" e "cumpre uma função primordialmente ideológica - e retrógrada" (ibid.). Assim, cabe deixar para trás a obsessão da "formação" do Brasil, e assumir a ideia de um permanente devir, sempre incompleto e aberto ao mundo.

Todavia, a recusa do nacionalismo jacobino, provinciano e confinador não significa diluir-se e dissolver-se num cosmopolitismo estandartizador, devendo ser acompanhada pela afirmação de um nacional não nacionalista. Cada povo precisa de marcos de referencia, vínculos e campos de sentido, para que seus membros possam se comunicar entre si, bem como para ser reconhecido e dialogar com os demais 
povos sem ser subjugado e espoliado. O alerta aqui é para quão armadilhosa é a questão identitária: a busca por descobrir, revelar e afirmar uma particular identidade é problemática, enganosa e destrutiva quando feita narcisisticamente e deixa de gravitar em torno do reconhecimento do outro como elemento da mesma, sem o qual se exacerbam medos e intolerâncias.

Esta "dialética do localismo e do cosmopolitismo" é, segundo Antonio Candido (1967: 129), "a lei de evolução da nossa vida espiritual”, e foi assim expressa nos anos 1920 tanto por Mário de Andrade - "todo e qualquer alastramento do conceito de pátria que não abranja a humanidade inteira me parece odioso" (apud Perrone-Moisés, 2007: 72) - quanto por Mariátegui - "dentro de nossas fronteiras acampa a humanidade" (1991: 367). Mais recentemente, também Aimé Césaire expos uma posição adequada sobre esta antinomia particular-universal:

Há dois modos de perder-se: por segregação muralhada no particular, ou por dissolução no "universal". [...] Minha concepção de universal é a de um universal depositário da profundização e coexistência de todos os particulares [...]. Universal, sim, porém faz já muito que Hegel nos mostrou o caminho: o universal, porém não por negação, mas como aprofundamento de nossa própria singularidade"(apud Bidaseca, 2010: 69).

Hoje, esclarece Nobre, “o vínculo tradicional entre 'centro' e 'periferia' mudou de caráter", uma vez que a subordinação internacional "já não segue o padrão inter-nacional” nem "se organiza em termos de nações, países ou Estados". De forma mais rápida e profunda que a revolução industrial, a revolução digital está a mudar os modos de vida e produção, potencializando um outro padrão de desenvolvimento diferenciado do dominante, fazendo brotar formas descentralizadas de acumulação baseadas em uma interatividade exponencial e no ressurgimento dos commons dela advindo. O modo ocidental expansivo e expropriativo de desenvolver as forças produtivas vai se esgotando. Na dinâmica societária contemporânea, conforme avaliam Antonio Negri e Giuseppe Cocco (2005: 34),

\footnotetext{
A transformação da dependência em interdependência coloca em evidência a nova situação: o mercado mundial não tem mais um lado de fora e os conflitos o atravessam em todos os seus níveis: entre o centro e a periferia, é certo, mas também no centro e na periferia. É esta a mudança que destroça qualquer perspectiva de construção de um projeto nacional-desenvolvimentista ou nacional popular (ou ainda nacionaldemocrático). A perspectiva do desenvolvimento perde seu horizonte nacional e, portanto, seus ilusórios atalhos tecnocráticos-autoritários.
}

Também do ponto de vista do perspectivismo, a antinomia centro e periferia é uma metáfora que já não tem mais valia, uma vez que a dinâmica global não amuralha e imobiliza os grupos humanos. Contudo, se nas redes os centros carecem de importância fulcral, o policentrismo multiescalar admite múltiplos centros: há centros nas periferias e periferias nos 
centros. Efetivamente, não há uma homogeneidade e indiferenciação espacial no conjunto da sociedade. A ausência de um centro absoluto e definidor, regente de todo universo, não implica que qualquer lugar seja o mesmo e que tudo seja plano, como defendeu Thomas Friedman (2005). Existem fluxos e pontos de intersecção que geram campos de força e se convertem em centros ad hoc que se projetam e conformam realidades, ainda que sem configurar uma integradora totalidade.

Mas, outra metáfora, agora de Viveiros de Castro (2015: 21), é perfeita para delinear a grande transformação em andamento: nosso povo está a despertar de um "coma étnico", pois tanto aos poucos nos livramos dos paradigmas eurocêntricos (inclusive o marxismo, entendido este como "ideologia" ou "doutrina"), como também vamos (re)descobrindo particularidades daquilo que somos e que até então não percebíamos e não conhecíamos, ou mesmo não entendíamos.

As "revoluções nacionais" na América Latina (inclusive a brasileira), que fizeram a independência e ergueram nossos Estados-Nação, não foram advindas das maiorias populares afro-ameríndias, mas das brancas elites crioulas, as quais então viviam assustadas com o fantasma do ocorrido em Santo Domingo (Haiti). É este o grupo social gerador da "nação" escolhida, cujas características configurarão a "essência nacional", uma vez que nacionalismo "significa a imposição de uma alta cultura em uma sociedade onde predominavam baixas culturas na maioria, se não na totalidade, da população. Significa a difusão de um idioma ..." (Gellner, apud Bresser Pereira, 2008). Assim, elas mantiveram as maiorias (que configuram outras inúmeras "nações") tão estigmatizadas, violentadas e subjugadas quanto nos mais de três séculos de escravidão. Ou seja, a condição colonial, para a grande parte do povo, não se alterou.

No caso brasileiro, são ainda mais acentuadas as linhas de continuidade entre nosso Estado-nacional e o passado colonial, face a nossa independência ter sido feita pelo próprio rei de Portugal; ou face a manutenção tanto da escravidão e da monarquia ao longo de quase sete décadas após a mesma, quanto da nossa própria integridade territorial (ao contrário do domínio espanhol). Os patrimônios das antigas oligarquias ficaram intocados, inclusive após a abolição. A proclamação da República em nada alterou o silenciamento do povo (que, aliás, se reagiu foi para defender o imperador), apenas renovou o olhar colonizador brasílico, agora impulsionado com o emblema "ordem e progresso", do qual o contemporâneo desenvolvimentismo dá continuidade. A primeira política educacional brasileira (e a primeira universidade) apenas surge na década de 1930.

$O$ ressurgimento da indianidade, a emergência e vigor da negritude, o revigoramento do campesinato (com as redes de agroecologia e de agricultura familiar) e uma 
consolidada despatriacarlização (emancipação feminina e de gênero) indicam o fim da branquidão, do domínio masculino e paulista (industrial) do projeto nacional, e são expressões da avassaladora fermentação social em curso no Brasil. Ao se cozinhar tudo isto no caldeirão de uma inserção cada vez mais globalizada de seus principais atores, teremos um profundo desmontar das perigosas e turbulentas armadilhas identitárias postas pela ideia de pureza de um "nacional" uno, originário, imutável e essencial, ao qual se deve uma lealdade incondicional. Assim, revelar-se-á o verdadeiro caráter do apelo retórico por sacrifícios em nome da "nação" e seu "desenvolvimento": um disfarce para a manutenção dos privilégios e da velha subalternidade colonial sobre as maiorias.

Estas fermentações equivalem à uma segunda descolonização, pois desafiam o padrão colonial de poder vigente na América Latina, retirando da invisibilidade populações excluídas classificadas como inferiores. Os que estão no polo de miséria do capitalismo reconquistam, com esforços individuais ou pela organização comunitária de seu trabalho, o acesso a bens e serviços, num autêntico processo de emancipação e democratização, redefinindo e ampliando, com suas cores, línguas e técnicas, a sociedade vigente e seu modelo europeu de Estado-nação uno e hegemônico.

Nossa hipótese é que o Brasil cada vez mais romperá com sua condição "decolonial" (se

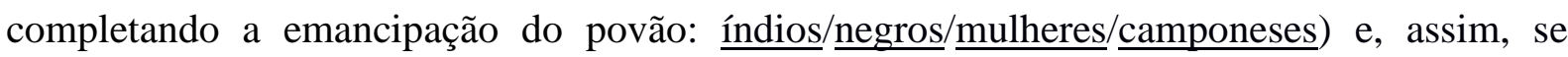
inserirá criativamente na vida global. Após os ciclos romântico e modernista dos séculos XIX e XX, surgem as condições para romper com as armadilhas iluministas e idealizadoras, que se fixavam na exaltação de elementos exóticos, folclóricos e demiúrgicos, seja na sua forma pura ou na sua assimilação e fusão, com vistas a adentrarmos dependentemente numa forçosa modernidade com base em quiméricas almas nacionais e em clichês patrióticos e grandiloquentes.

O Brasil do século XXI, portanto, paulatinamente descortina-se: de forma inclusiva (rompendo claramente com a subalternização da sua "ralé"); aberto para o mercado; e inserido internacionalmente. Ouso afirmar que, pela primeira vez, o Brasil como um todo, ou melhor, o arco-íris do povo brasileiro, diverso e plural, está prestes a se emancipar dos projetos cupulistas de "nação". Estes projetos, como é sabido, mais resultam de disputas e conflitos entre os interesses econômicos das elites que controlam o Estado, do que expressam as vontades populares. 


\section{CONSIDERAÇÕES FINAIS}

“A ideia de 'meio ambiente' pressupõe que nós, humanos, estamos no centro e as coisas moram à nossa volta. $\mathrm{Na}$ realidade, as coisas não nos rodeiam, nós formamos com elas um mesmo mundo, somos coisas e gente habitando um invisível corpo" (Mia Couto).

Não há humanização sem outridade, como proclamam enfaticamente seja a filosofia africana do Ubuntu - "Umuntu ngumuntu ngabantu" ("uma pessoa é uma pessoa através de outras pessoas", provérbio Zulu) - seja a descoberta do inconsciente pela psicologia moderna. "As pessoas são como palavras, só tem sentido se junto das outras", canta Emicida. Isto é: a alteridade é constitutiva do humano, o outro me constitui, para ser eu careço do outro. Parodiando Simone de Beauvoir, o ser humano não nasce ser humano, ele torna-se gente ao longo de sua vida, e condição sine-qua-non para tal é a dimensão de alteridade.

Uma pretensa diferença ontológica entre colonizador e colonizado é o elemento central e gerador da condição colonial, desumanizando e embrutecendo a ambos. Quando cotidiana e metafisicamente o outro é negado, quando o reduzo ao mesmo e obstinadamente não reconheço a sua humanidade, descartando-o na vala do não-ser, uma estranheza radical (a recusa da alteridade) dá lugar e comanda degenerativamente a política e a sociedade, de modo que a alteridade original e constitutiva da vida transfigura-se numa forma absolutamente antagônica e mortal, atrofiando e mutilando a condição humana, tanto de quem é espoliado, quanto do espoliador. A tomada do poder, esclareceu Fanon, não é condição suficiente para definir uma transformação autêntica e profunda, a qual gravita na órbita do ser: são mudanças concretas na vida (e de vida) das pessoas comuns (e não propostas abstratas e gerais) que desfazem o mundo do não ser, restabelecendo a humanidade dos subalternizados e, por tabela, também dos espoliadores.

Se "ser humano" é estar num permanente processo de humanização, mudar a vida de modo a libertar-se da coisificação e das carências de sua condição social, especialmente quando se desfaz a linha divisória entre aqueles que "são" e os que "não-são", perfaz uma mutação ontológica mais profunda e verdadeira que os golpes de Estado e a tomada do poder, que em geral não revolucionam nada, a não ser os dirigentes que nele se instalam. E, como naqueles esforços inclusivos também prima uma postura biocêntrica de conexão interativa com a natureza (de reverência à Pachamama, pois dela participamos: "somos a Terra"), trata-se, portanto, de um giro 
ontológico, uma autêntica mudança tectônica onde uma ontologia relacional (Escobar, 2014) desloca e ultrapassa o império da cosmovisão antropocêntrica e ocidental de corte dualista e reducionista.

À luz da luta de Frantz Fanon pela libertação da colonialidade, do reconhecimento da outridade de Tzvetan Todorov, e da ótica pluriversal de Arturo Escobar, afirmo que as lutas pela dignidade e os esforços autonômicos e includentes são lutas e processos ontológicos, pois visam, em primeiro lugar, a superação da colonial condição de "não-ser" e o restabelecimento da plena humanidade.

Enfim, o planeta fome desperta, literalmente, do "sonho colonial" (Fanon, 1968: 109). Talvez não exatamente como desejado pelos genéricos e unificados anseios da longa tradição brasileira de pensamento crítico de esquerda (Caio Prado; Florestan; Gorender; lanni ...), ou seja, com perfil socialista, estatista e igualitário, pois é um Brasil que anseia por se inserir no mundo do consumo e vencer com suas próprias forças e mérito, e não amparado pelo Estado. Mas é um Brasil novo, mais criativo e aberto às possibilidades libertadoras do gênero humano, com maior integração: por nele ressoar uma raiz comunitária (seja a das favelas, seja a do campo ou dos povos indígenas), está impulsionado por um metabolismo econômico possuidor de caráter mais responsável e respeitoso da natureza e do ser humano, gerador de dinâmicas de "desenvolvimento" territorial decoloniais e restabelecedoras da vida. 


\section{REFERÊNCIAS}

ANDRADE, Oswald. "Manifesto antropófago": A utopia antropofágica. São Paulo: Globo, 1990.

ARANTES, Paulo "Providências de um crítico literário na periferia do capitalismo". In:

ARANTES, Paulo; ARANTES, Otília. Sentido da formação. São Paulo: Paz e Terra, 1997.

BARTOLOMÉ, Miguel. "Las etnogénesis, viejos actores y nuevos roles en elescenario cultural y político”. In: Procesos interculturales. México: Siglo XXI, 2006.

BARTRA, Armando. El hombre de hierro. México: UACM, 2008.

BENTES, Ivana. O que pode um funk? 2017. Disponível em:

$<$ https://revistacult.uol.com.br/home/anitta-vai-malandra-ivana-bentes/>.

“Respeitosamente vândala”. Cult, n. 188, 2014, p. 7-10.

BIDASECA, Karina. Perturbando el texto colonial. Buenos Aires: SB, 2010.

BONFIL BATALLA, Guillermo. Utopia y revolución. México: Nueva Imagen, 1981.

BRESSER-PEREIRA, Luiz. "Nacionalismo no centro e na periferia do capitalismo". Estudos Avançados, n. 62, 2008. Disponível em:

<http://www.scielo.br/scielo.php?script=sci_arttext\&pid=S0103-40142008000100012>.

CANDIDO, Antonio. Literatura e sociedade. São Paulo: Nacional, 1967.

CARNEIRO, Maria J. "Ruralidade: novas identidades em construção". Estudos Sociedade e Agricultura, Rio de Janeiro, n. 11, outubro, 1998.

CLASTRES, Pierre. A sociedade contra o Estado. RJ: Francisco Alves, 1978.

CUNHA, Manuela. História dos índios no Brasil. SP: Cia. das Letras, 1992.

ESCOBAR, Arturo. Sentipensar con la tierra. Medellin: UNAULA, 2014.

FANON, Frantz. Os condenados da terra. Rio de Janeiro: Civilização Brasileira, 1968.

FRIEDMAN, Thomas. O Mundo é Plano. Rio de Janeiro: Objetiva, 2005.

GONÇALVES, Marcos A.. 1922: a semana que não terminou. São Paulo: Cia das Letras, 2012.

HOWARD, Ebenezer. Cidades-jardins de amanhã. 2. ed. São Paulo: Hucitec-Annablume, 2002.

LISBOA, Armando. "Economia, idolatria, charlatanice". In: Studium, Curitiba, ano 8, n. 13, 2014. Disponível em: 〈https://claretiano.edu.br/revista/66/teologia-e-questoes-de-idolatria〉. 
LISBOA, João Francisco. Acadêmicos indígenas em Roraima e a construção da interculturalidade indígena na universidade: entre a formação e a transformação. Brasília: Unb (tese de doutorado em Antropologia), 2017.

MARIÁTEGUI, José. Textos básicos. Lima: FCE, 1991.

MARICATO, Ermínia. "Os prisioneiros da especulação imobiliária” (entrevista). Caros Amigos, n. 158, maio, 2010. Disponível em: <http://csbh.fpabramo.org.br/node/7118>.

NEGRI, Antonio; Cocco, Giuseppe. Glob(AL). Rio de Janeiro: Record, 2005.

NOBRE, Marcos. “Depois da 'formação"”. PIAUÍ, n. 74, p. 74-77, 2012.

PERRONE-MOISÉS, Leyla. Vira e mexe, nacionalismo. São Paulo: Cia. das Letras, 2007.

SANTOS, Marize; FONSECA, Said. "Farmácias Vivas". In: Brasil. Ministério da Saúde. Praticas integrativas e complementares: plantas medicinais e fitoterapia na Atenção Básica, 2012. Disponível em:

<https://cursos.atencaobasica.org.br/sites/default/files/farmacias_vivas_0.pdf>.

SANTOS, Milton. A natureza do espaço. 3. ed. São Paulo: Hucitec, 1999.

TODOROV, Tzvetan. A vida em comum. Campinas: Papirus, 1996.

VARGAS LHOSA, Mário. Sabres e utopias. Rio de Janeiro: Objetiva, 2010.

VEIGA, José Eli. Cidades imaginárias. Campinas: Autores Associados, 2002.

VIVEIROS DE CASTRO, Eduardo. “O recado da mata (prefácio)”. In:KOPENHAWA, Davi; ALBERT, Bruce. A queda do céu. São Paulo: Cia. das Letras, 2015.

ZAGO, Nadir. "Cursos pré-vestibulares populares: limites e perspectivas".Perspectiva, v. 26, p. 149-174, 2008. 